\title{
China, India, and the Social Construction of Technology in International Society: The English School Meets Science and Technology Studies
}

\begin{abstract}
In recent years, there has been a growing scholarly interest in how International Relations theory can contribute to our understanding of the impact of technology on global politics, underpinned mainly by an engagement with Science and Technology Studies (STS). However, less attention has been paid to the ways in which international society shapes technology. Building on sociological and historical studies of science and technology, this article outlines one way through which international society has constituted technology by developing a synthetic account of the emergence of technological advancement as a 'standard of civilisation' in the nineteenth century that differentiated the 'society of civilised states' from non-European societies, with a particular focus on China and India. In doing so, this article also highlights how this process has had a powerful and enduring influence on Chinese and Indian conceptions about science and technology. Thus, by shifting the focus from how technology shapes global politics to how international society shapes technology, this article provides new insights into the relationship between technology, power, and modernity in an interdisciplinary context. It also offers a new way of thinking about the complex dynamics of today's global politics of technology.
\end{abstract}

\section{Keywords}

Technology, 'Standard of Civilisation', China, India, International Society

\section{Introduction}


One of the key qualities of contemporary international society has been the role of technology and the subsequent transformation it has brought about in the conduct of international relations. It is not surprising, therefore, that there has been a burgeoning literature that deals with certain aspects of the global politics of technology, which has largely been organised around the examination of theoretical approaches to the study of current security issues and global governance challenges from an International Relations (IR) theory perspective. ${ }^{1}$

To be sure, the importance of technology has long been recognised by IR scholars. However, most scholars have been predominantly concerned with the material and strategic factors driving key technological projects. Furthermore, traditional IR approaches have offered accounts of the role of technology in global politics characterised largely by technological determinism and ahistoricism. ${ }^{2}$ Recent IR scholarship, by

\footnotetext{
${ }^{1}$ Examples are: Madeline Carr, 'Power plays in global internet governance', Millennium, 43:2 (2015), pp. 640-59; Geoffrey L. Herrera, Technology and International Transformation: The Railroad, the Atom Bomb, and the Politics of Technological Change (Albany: State University of New York Press, 2006); Daniel H. Deudney, Bounding Power: Republican Security Theory from the Polis to the Global Village (Princeton, NJ: Princeton University Press, 2007); Mary Manjikian, 'Becoming Unmanned', International Feminist Journal of Politics, 16:1 (2014), pp. 48-65; Maximilian Mayer, Mariana Carpes, and Ruth Knoblich (eds), The Global Politics of Science and Technology - Vol. 1: Concepts from International Relations and Other Disciplines (Heidelberg: Springer, 2014); Columba Peoples, Justifying Ballistic Missile Defence: Technology, Security and Culture (Cambridge: Cambridge University Press, 2010).

2 Daniel R. McCarthy, 'Introduction: Technology in World Politics', in Daniel R. McCarthy (ed.), Technology and World Politics: An Introduction, (London: Routledge, 2018), p. 2. For good overviews of the traditional IR approaches to technology, inter alia, see Madeline Carr, US Power and the Internet in
} 
contrast, has paid attention to the relationship between power and technology, with a particular focus on how technology transforms international relations. ${ }^{3}$ Equally, there has been a growing interest in how technology is conditioned by social forces and political ideas, underpinned by an engagement with Science and Technology Studies (STS) generally, and with the Social Construction of Technology (SCOT) and Actor-Network Theory (ANT) in particular. ${ }^{4}$

While this literature helps us to appreciate the ways in which technology is shaped by the dynamics of social and political forces and how it affects international relations, limited attention has been paid to the ways in which international society shapes technology. Yet it is one of the central conceptual claims of the following discussion that to understand the interplay between technology and international relations, it is necessary to relate technology to the analytical idea of international society, associated with the

International Relations (Basingstoke: Palgrave Macmillan, 2016); Stefan Fritsch, 'Technology and global affairs', International Studies Perspectives, 12:1 (2011), pp. 27-45; Herrera, Technology and International Transformation; and McCarthy, 'Introduction'.

${ }^{3}$ Barry Buzan and George Lawson, The Global Transformation: History, Modernity and the Making of International Relations (Cambridge: Cambridge University Press, 2015); and Herrera, Technology and International Transformation.

${ }^{4}$ See, for example, Madeline Carr, US Power and the Internet; Herrera, Technology and International Transformation; Fritsch, 'Technology'; Maximilian Mayer and Michele Acuto, 'The Global Governance of Large Technical Systems', Millennium, 43:2 (2015), pp. 660-83; Daniel R. McCarthy, Power, Information Technology, and International Relations Theory (Basingstoke: Palgrave Macmillan, 2015); Daniel R. McCarthy (ed.), Technology and World Politics: An Introduction (London: Routledge, 2018). 
English School. ${ }^{5}$ The English School's main concern is the rules, norms, and institutions that bound states as members of an international society, which is commonly differentiated from the international system. Significantly, within the English School perspective, institutions are not international governmental organisations, but 'a set of habits and practices shaped towards the realisation of common goals' ${ }^{6}$ By making this conceptual move of relating technology to the framework of international society, the article considers how a civilisation dimension was ascribed to the role of high technology that differentiated the 'society of civilised states' from non-European societies in the nineteenth century. This is an important, but largely overlooked, aspect of the growing literature on the global politics of technology, not least because this civilisation dimension has informed powerful and enduring conceptions of technology as markers of power, status, and modernity that still resonate today.

\footnotetext{
${ }^{5}$ Hedley Bull, The Anarchical Society: A Study of Order in World Politics, (3rd edn, Basingstoke: Palgrave, 2002.

${ }^{6}$ Bull, The Anarchical Society, p. 71. Bull identifies the balance of power, the managerial role of great powers, diplomacy, international law, and war as the key institutions of international society that underpin the maintenance of international order. It should be noted that Barry Buzan has introduced the terminology of primary institutions and secondary institutions to highlight the constitutive and fundamental nature of the former, which is employed in this article. See, Barry Buzan, From International to World Society? English School Theory and the Social Structure of Globalisation (Cambridge: Cambridge University Press, 2004). On the English School, inter alia, see Buzan, From International to World Society; Andrew Hurrell, On Global Order: Power, Values and the Constitution of International Society (Oxford: Oxford University Press, 2007); Andrew Linklater and Hidemi Suganami, The English School of International Relations: A Contemporary Reassessment (Cambridge: Cambridge University Press, 2006); Cornelia Navari and Daniel M. Green (eds.), Guide to the English School in International Studies (Chichester: Wiley Blackwell, 2014).
} 
More specifically, building on sociological and historical studies of science and technology, this article focuses on the emergence of 'high-visibility technology' as a 'standard of civilisation' in the nineteenth century. In doing so, it examines how technology was increasingly seen as a measure of the level of civilisation in the nineteenth century, embedded in a techno-scientific orientalist discourse, what can be called 'technoscientific orientalism', which contributed to the construction of hierarchical conceptions of modern science and technology. ${ }^{7}$ As such, it was part of the wider orientalist discourse surrounding the construction of a series of binary oppositions between the European self and the non-European Other. ${ }^{8}$ The article then moves on to consider how this process has had a powerful and enduring impact on Chinese and Indian conceptions about science and technology.

The article, therefore, shares the view that one of the key aspects of the European expansion has been the 'standard of civilisation' based on an inner circle of Western 'core' members, led by the European colonial powers, and a non-Western outer tier, and

\footnotetext{
${ }^{7}$ In this context, it is important to acknowledge that ideas about science, especially the appeal to nature in scientific aspects of civilisational standards were important along with ideas about technology. In many ways, then, technology emerged as the register through which scientific arguments about race were made. I would like to thank one anonymous reviewer for pointing this out. However, this article is primarily focused on 'high-visibility technology', which refers to the demonstrative effect of some technologies that allows for their celebration as great technological and engineering feats and consequently as a purported affirmation of self-proclaimed civilisational superiority and/or national technological prowess.

${ }^{8}$ Edward Said, Orientalism (New York, NY: Pantheon Books, 1978).
} 
so it draws on debates about the relevance of the 'standard of civilisation' in understanding particular norms, practices, and institutions that have influenced international society since the nineteenth century. ${ }^{9}$ In this regard, it suggests that technological advancement went hand in hand with the construction of civilisational hierarchies and other standards of 'civilisation' in racialised terms by each feeding into the other. The article also shares many of the assumptions of the SCOT approach and its commitment to shedding light on the relationship between power and technology in the context of international relations.

This conceptual rethinking is important for a number of reasons. First, framing technology as a 'standard of civilisation' makes it possible to identify some of the shortcomings in the literature on technology and IR by shifting the focus from how technology shapes global politics to how international society has shaped technology, with enduring implications for today's global politics of technology, as noted earlier. Indeed, as Daniel McCarthy notes, IR scholarship has paid much attention to the former,

\footnotetext{
${ }^{9}$ Gerrit W. Gong, The Standard of 'Civilisation' in International Society (Oxford: Clarendon Press, 1984). See also Brett Bowden, The Empire of Civilization: The Evolution of an Imperial Idea (Chicago, IL: University of Chicago Press, 2009); Barry Buzan, 'The 'Standard of Civilisation' as an English School Concept, Millennium, 42:3 (2014), pp. 576-94; Edward Keene, Beyond the Anarchical Society: Grotius, Colonialism and Order in World Politics (Cambridge: Cambridge University Press, 2002); and Ann Towns, 'The status of women as a standard of 'civilization', European Journal of International Relations, 15:4 (2009), pp. 681-706. For an overview of the different uses of this concept, see Dimitrios Stroikos, 'Introduction: Rethinking the Standard(s) of Civilisation(s) in International Relations, Millennium, 42:3 (2014), pp. 546-56.
} 
but it has neglected the latter. ${ }^{10}$ Second, this rethinking also serves to illustrate how a historical-informed analysis helps to account for influential ideas about power and technology that inform the pursuit of key public technological projects, such as nuclear and space programmes, which define hierarchies and international social stratification in today's international society. ${ }^{11}$ Most of these ideas, the article suggests, are rooted in the nineteenth century. Such a focus is also in line with recent works that have highlighted the impact of the 'global transformation' of the long nineteenth century on the current international order, especially with regards to the relationship between state, power, and modernity. ${ }^{12}$ Third, linking technology with the 'expansion thesis', and the cases of China and India in particular, helps not only to highlight continuities and discontinuities in the relationship between power and technology, but it also illuminates the agency of Chinese and Indian elites as part of a complex process of resisting, contesting, negotiating, and appropriating hegemonic conceptions of technology as sites of power. This is an

\footnotetext{
${ }^{10}$ McCarthy, 'Conclusion: Technology and International Relations Theory', in Daniel R. McCarthy (ed.), Technology and World Politics: An Introduction (London: Routledge, 2018), p.225. Notably, some work has been done from an English School perspective that deals with particular cases related to the politics of technology. For example, see William Walker, A Perpetual Menace: Nuclear Weapons and International Order (London: Routledge, 2012). See also Dimitrios Stroikos, Engineering world society? Scientists, internationalism, and the advent of the Space Age, International Politics, 55:1 (2018), pp. 73-90. But, to date, there has not been any effort to engage with the STS literature.

${ }^{11}$ Paul Musgrave and Daniel H. Nexon, 'Defending Hierarchy from the Moon to the Indian Ocean: Symbolic Capital and Political Dominance in Early Modern China and the Cold War', International Organization, 72:3 (2018), pp. 591-626.

${ }^{12}$ Buzan and Lawson, The Global Transformation; Jennifer Mitzen, Power in Concert: The Nineteenth Century Origins of Global Governance (Chicago, IL: University of Chicago Press, 2013).
} 
important consideration, given that China and India continue to prioritise technological prowess as emerging non-Western technological powers. ${ }^{13}$

What merits emphasis, for the purposes of this discussion, is that this article employs a broadened concept of technology. Clearly, conceptualising technology has presented knotty analytical challenges, especially when trying to make sense of the complex relationship between science and technology. ${ }^{14}$ One response has been to associate science with 'amassing knowledge about and seeking understanding of the cosmos and the mundane world', while the pursuit of technology has been seen as associated primarily with 'solving practical problems and exerting control over nature' ${ }^{15}$ However, this article shares Michael Adas' view that such a distinction is unhelpful, given that the boundaries between scientific research and technology were becoming increasingly blurred from the nineteenth century onwards as a consequence of a new phase of industrial development. ${ }^{16}$

\footnotetext{
13 Andrew B. Kennedy, 'Powerhouses or pretenders? Debating China's and India's emergence as technological powers', The Pacific Review, 28:2 (2015), pp. 281-302.

${ }^{14} \mathrm{I}$ am aware that there is an ongoing debate within STS regarding the relationship between science and technology. For a good overview of this debate, see Paul Forman, 'The primacy of science in modernity, of technology in postmodernity, and of ideology in the history of technology', History and Technology, 23:1-2 (2007), pp. 1-152. Also, see Sungook Hong, 'Historiographical layers in the relationship between science and technology', History and Technology, 15:4 (1999), pp. 289-311. Forman argues, rather controversially, that science became 'subsumed under technology' in the second half of the twentieth century.

${ }^{15}$ Michael Adas, Dominance by Design: Technological Imperatives and the America's Civilizing Mission (Cambridge, MA: Harvard University Press, 2006), p. 12.

${ }^{16}$ Ibid, pp. 12-13. On this point, see also David F. Channell, A History of Technoscience: Erasing the Boundaries between Science and Technology (Abingdon: Routledge, 2017).
} 
Significantly, this broadening of the concept helps to highlight how the operation of technology as a 'standard of civilisation' has been closely tied to other standards. For example, it speaks to those interested in the theoretical and empirical study of the construction of non-proliferation and arms control premised on civilisational practices and discourses that confine the possession of certain weapons to the club of 'civilised' countries, enmeshed in the logic of the 'standard of civilisation'. ${ }^{17}$ Similarly, the argument is also relevant to the idea that the control of nature emerged as standard in the nineteenth century. ${ }^{18}$ Consequently, the central argument of this article enables us to ask a new series of crucial questions about the relationship between technology and international society: In what ways has the expansion of the European international society shaped powerful ideas about technology? What was the impact of the emergence of technology as a 'standard of civilisation' on China and India? What are the origins of techno-nationalism in international society? What explains the enduring relevance of

\footnotetext{
${ }^{17}$ Keith Krause and Andrew Latham, 'Constructing non-proliferation and arms control: The norms of Western practice', Contemporary Security Policy, 19:1 (1998), pp. 41-4; Richard Price, 'A Genealogy of the Chemical Weapons Taboo', International Organization, 49:1 (1995), pp. 73-103; Nina Tannenwald, 'The nuclear taboo: The United States and the normative basis of nuclear non-use', International Organization, 53:3 (1999), p. 437.

${ }^{18}$ Joanne Yao, 'Conquest from barbarism': The Danube Commission, international order and the control of nature as a Standard of Civilization', European Journal of International Relations, 25:2 (2019), 335-59.
} 
conceptions of technology as a normative indicator of power, status, and modernity in China and India today?

The article is organised in the following way: The first part revisits the concept of the 'standard of civilisation' and then moves on to review the ways in which technological achievements were represented as markers of the superiority of Western civilisation in the nineteenth century and how China and India were seen as 'uncivilised', based on European perceptions of their technological backwardness. The second part of the article then briefly considers how the social pressure created by the need to conform to the operation of technological advancement as a civilisational standard was one of the key drivers behind late Qing China's technological modernisation. It also highlights some of the principal aspects of the nexus between science, technology, and modernity in British India and the Indian responses that this process elicited. The key point to emphasise here is how China and India's encounter with the European international society and the construction of technological advancement as a 'standard of civilisation' informed, to varying degrees, the development of technology in China and India during that period as a normative marker of the state's civilisation, power, and status. As we shall see, this conception of technological advancement still informs certain Chinese and Indian technological projects. 


\section{The 'Standard of Civilisation'}

One of the most important aspects of the modern structure of international society has been the expansion of the European international society into the non-European world and the subsequent great transformation of regulating international relations it brought about in the nineteenth century as a consequence. Although it is clear that a complex amalgam of factors played a decisive role in shaping the ways in which non-European states came to accept key European institutions, norms, and practices in the conduct of their international relations, for the purposes of this discussion, the important feature of this process has been the 'standard of civilisation', based on civilisational and racial hierarchies in a context of uneven and combined development. ${ }^{19}$

A detailed discussion of the evolution of the 'standard of civilisation' in international society is beyond the scope of this article, but the point to emphasise is that the underlying logic of the 'standard of civilisation' was evident in how the classification of 'civilised', 'barbarian', and 'savages' was used by international lawyers as three categories consistent with different stages of legal recognition. A key dimension of the operation of

\footnotetext{
19 Buzan, 'The 'Standard of Civilisation', Gong, The Standard of 'Civilisation'. On the 'standard of civilisation' and uneven and combined development see, Buzan and Lawson, The Global Transformation; and Alex Anievas and Kerem Nisancioglu, How the West Came to Rule: The Geopolitical Origins of Capitalism (London: Pluto Press, 2015), pp. 127, 134.
} 
the 'standard of civilisation' as a legal principle, therefore, was that those political entities aspiring to be brought within the confines of the perceived international society of 'civilised' states had to fulfil a number of requirements set by the European society of states in order to be recognised as full members states. ${ }^{20}$ Against this backdrop, the need for adjusting to Western style standards usually involved the introduction of alien values and norms to their culture, and, hence, the dilemma of how to balance traditional culture with modernity and reforms. ${ }^{21}$ It is in this context that the cases of Japan, China, Russia, and the Ottoman Empire have generated debates about their encounter with European international society and their struggle with the 'standard of civilisation'. ${ }^{22}$

Nevertheless, it is worth noting that the process of recognition as a member of the expanding European international society was a good deal more complex. In particular, Japan is usually invoked as the first non-European state that met the 'standard of civilisation' and was successfully accepted as a member into international society. ${ }^{23}$ However, the 1895 Triple Intervention by Russia, France, and Germany after the first Sino-Japanese War and the denial of racial equality clause by key Western powers at the

\footnotetext{
${ }^{20}$ Gong, The Standard of 'Civilisation'. See also Antony Anghie, Imperialism, Sovereignty and the Making of International Law (Cambridge: Cambridge University Press, 2004); and Gerry J. Simpson, Great Powers and Outlaw States: Unequal Sovereigns in the International Legal Order (Cambridge: Cambridge University Press, 2004), pp. 227-53.

${ }^{21}$ Gong, The Standard of 'Civilisation', pp. 6-14.

${ }^{22}$ Buzan, 'The 'Standard of Civilisation'.

${ }^{23}$ Ibid, p. 583.
} 
Paris Peace conference in 1919 are testimony to the tensions and contradictions that were central to the process of the 'standard of civilisation' as a universal process. ${ }^{24}$ After all, it is useful to remember that the European society of states was characterised by multiple layers of differentiation even among its members. ${ }^{25}$

Be that as it may, the point to emphasise here, for the purposes of this discussion, is that it is simply impossible to consider the emergence of the 'standard of civilisation' in the nineteenth century without recognising how a civilisation dimension was central to technological achievements in international relations in the context of the expansion of the European international society and how this process reinforced not only the sense of European superiority, but also the link between the state, technology, and modernity. It is here that contributions from the history and sociology of technology are potentially helpful in illuminating the wider historical context that defined the impact of scientific and technological accomplishments as a key feature of the expansion of the European international society.

Before considering that, however, a caveat should be noted. One of the most enduring and influential assumptions has been the centrality of science and technology in Western

\footnotetext{
${ }^{24}$ Tomoko T. Okagaki, The Logic of Conformity: Japan's Entry into International Society (Toronto: Toronto University Press, 2013), p. 117; Gong, The Standard of 'Civilisation', pp. 63, 196-9.

${ }^{25}$ Simpson, Great Powers and Outlaw States; See also Edward Keene, 'The Standard of 'Civilisation', the expansion thesis and the 19th-century international social space', Millennium, 42:3 (2014), pp. 651-73.
} 
civilisation and the ignorance of the sciences of other cultures, based on the idea of a Great Divide between the 'scientific West' and its 'intuitive East'. This has culminated with an analytical property of a Eurocentric and hierarchical understanding of the relationship between science and civilisation, which often entails 'comparisons of civilizations along normative teleologies of moral, political, scientific, or economic progress' ${ }^{26}$

My intention, therefore, is not to advocate a Eurocentric conception of science and technology that seeks to deny Eastern agency from the global history of science and technology, but to try to understand and explain how notions of Western superiority and hierarchy based on the state of scientific and technological development have had profound implications in the context of the whole 'standard of civilisation' question, notwithstanding how discomforting their telling may be. Hence, it seems clear to me that trying to shed some light on a rather neglected aspect of the modern history of international society is not thereby endorsing it.

Technological Advancement and Civilisational Hierarchies

\footnotetext{
${ }^{26}$ Roger Hart, Imagined Civilizations: China, the West, and Their First Encounter (Baltimore, MD: Johns Hopkins University Press, 2013), p. 35.
} 
One of the most important contributions that historically-informed analyses have made is in interrogating how science and technology were used by Western countries after the Industrial Revolution to establish a Western ideology that justified concepts of Western superiority, dominance, and colonialism as part of their 'civilising mission'. In his seminal work on science and technology, Adas persuasively demonstrates how scientific and technological achievements became an indication of what it meant to be 'civilised' ${ }^{27}$ Simply put, underpinning Western ideologies of dominance was the notion that scientific and technological accomplishments were markers of the level of civilisation a given society had achieved. Likewise, Daniel Headrick shows how technological advancements were a crucial factor in colonial expansion and empire-building, ${ }^{28}$ while Lewis Pyenson (1993) offers an account of how the spread of exact sciences to the colonies was a key element of the French 'civilising mission'. ${ }^{29}$

More broadly, the origins of science and technology as representations of cultural authority can be traced back to the first phase of overseas expansion during the fifteenth

\footnotetext{
${ }^{27}$ Michael Adas, Machines as the Measure of Men: Science, Technology, and Ideologies of Western Dominance (Ithaca, NY: Cornell University Press, 1989).

${ }^{28}$ Daniel R. Headrick, The Tools of Empire: Technology and European Imperialism in the Nineteenth Century (New York, NY: Oxford University Press, 1981).

${ }^{29}$ Lewis Pyenson, Civilizing Mission: Exact Sciences and French Overseas Expansion, 1830-1940 (Baltimore, MD: John Hopkins University Press, 1993).
} 
century. But although the role of scientific and technological accomplishments in influencing broader categorisations of non-European peoples as civilised or barbarian was relatively limited before the Industrial Revolution, from the 1780 s onwards, machines gradually became emblems of the level of civilisation a given society had attained..$^{30} \mathrm{~A}$ number of points are worth noting here. First, it is necessary to emphasise that technological innovation and gauges never assumed the formal status of legal, political, and diplomatic standards of the sort described in the relevant literature on the 'standard of civilisation'. Rather, technological feats served as an informal, but significant, marker of ordering polities along the stages of civilisation and progress. ${ }^{31}$ In this respect, technological advancement as an informal standard provided a framework for expectations about the proper place of science and technology within the context of state and modernity that indicated the differing levels of material and social development.

Second, one reason for thinking that technological achievements emerged as meaningful measures of human development, progress, and civilisation by the nineteenth century is because they could be empirically observed. Equally importantly, in addition to their function as physical and symbolic indicators of the superiority of European

\footnotetext{
${ }^{30}$ Adas, Machines, pp. 21-68.

${ }^{31}$ On a similar point with regards to the status of women as an informal 'standard of civilisation', see Towns, 'The status of women', p. 694.
} 
colonial powers, technological attainments were also seen to embody a set of more subtle superior attributes, such as rationality, the mastery of time and space, precision, and discipline. ${ }^{32}$ This point is significant because it helps to illustrate how technology as a 'standard of civilisation' was closely related to other standards associated with the same qualities of 'civilised' statehood, including the control of nature and the conduct of 'civilised' warfare, as we saw previously, which were often blended into each other.

Third, the emergence of technological advancement as a standard contrasts with other competing conceptions and visions that emerged in the same period, revolving around the idea of science and technology as the unifier of humankind. ${ }^{33}$ This sort of internationalism was evident in the formation of the International Telecommunications Union, the world's first intergovernmental organisation. ${ }^{34}$ But, their military uses aside, this did not prevent the telegraph, the railways, and other communications technologies to be simultaneously seen as 'civilising' forces. ${ }^{35}$ Besides, it was more often than not that the idea of the scientific community was exclusive, limited to the 'civilised' family of nations. ${ }^{36}$ What

\footnotetext{
${ }^{32}$ Adas, Machines, pp. 7, 224.

${ }^{33}$ Mark Mazower, Governing the World: The History of an Idea (London: Allen Lane, 2012), pp. 94-104.

${ }^{34}$ Douglas Howland, 'An alternative mode of international order: The international administrative union in the nineteenth century', Review of International Studies, 41:1 (2015), pp. 161-83.

${ }^{35}$ Ben Marsden and Crosbie Smith, Engineering Empires: A Cultural History of Technology in NineteenthCentury Britain (Basingstoke: Palgrave Macmillan, 2005), pp. 216, 231-2. See also Adas, Machines, pp. 221-36.

${ }^{36}$ Geert J. Somsen, 'A history of universalism: Conceptions of the internationality of science from the Enlightenment to the Cold War', Minerva, 46 (2008): pp. 363-4.
} 
should also be mentioned is that the construction of the 'Other' as 'barbarous' in terms of technology occurred even though 'barbarous' countries such as China and India had developed sophisticated technologies in the past, and despite the fact that the transnational flow of scientific knowledge and technological innovation meant that the relationship between Europe and the colonies was a two way street. ${ }^{37}$

Given this background, of particular significance here is the need to understand the representation of material achievements as a key element of the political ideology that imbued the political thought and public life in key colonising powers, such as Britain and France. While a detailed discussion of the quite different understandings of the relationship between technology and civilisation of that period is beyond the scope of this article, it is worth briefly considering some of the most influential works, especially those with a focus on China and India.

In this context, a wide range of European observers, authors, politicians, public officials, engineers, and travellers offered explicit accounts of the close synergy between technological accomplishments and civilisation, and their more subtle attributes, enmeshed in a techno-scientific orientalist discourse. Some of those came to draw conclusions about the level of Chinese and Indian civilisation by providing an extensive

${ }^{37}$ John M. Hobson, The Eastern Origins of Western Civilisation (Cambridge: Cambridge University Press, 2004). 
account of their technological achievements in the nineteenth century. Of course, not everyone supported the idea that China and India should be evaluated and ranked as 'uncivilised' on scientific and technological criteria, while some authors acknowledged the contributions of the Chinese and Indian civilisations to scientific knowledge and technological progress, at least in ancient times. Nevertheless, the views of influential authors, such as those of John Barrow and James Mill, are illustrative of the ways in which technological achievements were articulated as a measure to evaluate China and India as 'uncivilised'. ${ }^{38}$

Barrow's Travels in China had been an authoritative source on Chinese society and history since its publication in $1804 .^{39}$ The book was the culmination of Barrow's participation in the first British diplomatic mission to China, known as the Macartney Embassy, which travelled from Beijing to Guangzou in 1792 with the aim of improving trade with the Qing Empire. While Barrow recognises that China had once achieved a high level of civilisation in terms of social development and material culture, he offers a negative account of China's perceived general backwardness in terms of technology and science. ${ }^{40}$ In discussing the use of Chinese tools and machines, Barrow notes that 'the

\footnotetext{
${ }^{38}$ Adas, Machines, p. 10.

${ }^{39}$ John Barrow, Travels in China (London: T. Cadel and W. Davies, 1804).

${ }^{40}$ On Barrow's background and the influence of his Travels in China, see Adas, Machines, pp. 178-83.
} 
great advantages attainable from the use of mechanical powers are either not understood or, purposely, not employed'. ${ }^{41}$ Left unimpressed, Barrow concludes that, although 'the Chinese have been among the first nations...to arrive at a certain pitch of perfection'...'more than two thousand years ago, at a period when all Europe might be considered, comparatively, as barbarous', 'they have since made little progress in any thing, and been retrograde in many things' ${ }^{42}$ While Travels in China did not receive the attention that Mill's History of British India would do some years later, Barrow's views and opinions about the level of Chinese scientific knowledge and technological innovation had an enduring impact on nineteenth century accounts of the Qing Empire and helped him to build a reputation as an authority on Chinese affairs. ${ }^{43}$

In a rather similar fashion, in his influential History of British India, Mill suggests that India has no mark of high civilisation because of the low state of scientific knowledge. ${ }^{44}$ After a rather detailed analysis of the use of key tools and machines by Indians, Mill notes that:

\footnotetext{
${ }^{41}$ Barrow, Travels, p. 311.

42 Ibid, p. 355.

${ }^{43}$ Adas, Machines, pp. 182-3.

${ }^{44}$ James Mill, History of British India, Vol 2. (4th edn, London: James Madden and Co., 1848).
} 
Whoever, in the present improved state of our knowledge, shall take the trouble to contemplate the proofs which we possess of the state of knowledge and civilization among the Hindus, can form no other conclusion, but that every thing (unless astronomy be an exception) bears clear, concurring, and undeniable testimony to the ignorance of the Hindus, and the low state of civilization in which they remain. ${ }^{45}$

Referring to 'Surya Sidhanta' as a proof of the contribution of Hindu civilisation to astronomical knowledge, Mill contends that 'it is on the authority of our own countryman I am enabled to declare, that this book [Surya Sidharta] is itself the most satisfactory of all proofs of the low state of the science among the Hindus, and the rudeness of the people from whom it proceeds' and he concludes that 'the ignorance [of Hindus] of the present age is the same with the ignorance of all former ages' ${ }^{46}$ Elsewhere in his History, citing Barrow's Travels in China, Mill briefly analyses the use of machines and tools by Indians and Chinese to find that 'in the contrivance and use of machinery both are equally simple and rude' ${ }^{47}$

\footnotetext{
${ }^{45}$ Ibid, p. 99.

${ }^{46}$ Ibid, pp. 100-1, 106.

${ }^{47}$ Ibid, p. 220.
} 
The publication of History helped Mill to take a position with the East India Company, where he eventually took over the post of Examiner of India Correspondence. Although other works appeared soon after its publication that provided a more balanced account of Indian society and history, it is important to note that his views appear to have significantly influenced the policies of reformist British administrators in India, as his History came to be regarded as the definite source on India for future British rulers, traders, and missionaries. That candidates for the Indian Civil Service had to read History as part of their training is also illustrative of its authoritative status at that time. ${ }^{48}$

Not surprisingly, perhaps, non-European countries responded to their encounter with European international society during the nineteenth century in intrinsically different ways. Japan provides again the model of a country that successfully placed emphasis on technological and industrial development during the Meiji period in order to be seen as equal with and independent from the West. ${ }^{49}$ Notably, one of the consequences of Japan's rapid technological and industrial transformation in its bid to be recognised as a 'civilised' great power was that it gradually posed a challenge to notions of Western superiority and hierarchy based on the state of its scientific and technological development. Arguably, as

\footnotetext{
${ }^{48}$ Adas, Machines, p. 171.

${ }^{49}$ Shogo Suzuki, Civilization and Empire: China and Japan's Encounter with European International Society (Abingdon: Routledge, 2009).
} 
noted earlier, Japan's entry into international society was a thorny and ongoing process, but it seemed to confirm the earlier interest among Asian reformists in the universal nature of modernity. This possibility was nowhere clearer than in Japan's stunning victory over Russia in 1904-5, which marked the first time that a non-European country had proved to be more mighty and modern than a European empire, albeit a weak one. The RussoJapanese War became a global moment of revaluating wide-held views about Western civilisation, colonial rule, and technological prowess, and reinforced the support among nationalists and intellectuals of China and India for equality with the West. ${ }^{50}$

Consequently, not only did the remarkable industrialisation of Japan over just a few decades demonstrate that it was a valuable model of modernisation for other Asian societies to follow, but it also put in question that the scientific and technological accomplishments of the Europeans were indicators of their racial superiority. ${ }^{51}$ Japan may be something of an extreme example with its emphasis on technological and industrial development. Still, the emergence of technological advancement as a measure of civilisation had an important impact on conceptions of technology in China and India in the long nineteenth century, to which I now turn.

\footnotetext{
${ }^{50}$ Cemil Aydin, The Politics of Anti-Westernism in Asia: Visions of World Order in Pan-Islamic and PanAsian Thought (New York, NY: Columbia University Press, 2007), pp. 71-82; Pankaj Mishra, From the Ruins of Empire: The Revolt Against the West and the Remaking of Asia (London: Allen Lane, 2012), pp. $1-7$.

${ }^{51}$ Adas, Machines, pp. 357-65.
} 


\section{China: The Pursuit of Technology and the 'Standard of Civilisation'}

Certainly, one of the most dramatic consequences of China's violent encounter with the expanding European International Society was to bring about the realisation among Chinese elites that institutional reforms were needed in order to adapt to the new international environment. The most important attempt to modernise was what is usually known as the Self-Strengthening Movement with the aim to enhance China's 'wealth and strength' ${ }^{52}$ In addition to the establishment of the Zongli yamen in 1861, an important institutional innovation intended to manage relations with major Western powers, there was also a growing appreciation of international law and diplomatic practices. ${ }^{53}$

It was this backdrop of internal tension and external pressure that provided the impetus for a shift towards the introduction of these reforms, including the adoption of Western technology, as part of the Qing restoration. There were a great many skilful officials who tried to contribute to the restoration of the empire by imbuing it with a sense of purpose, bolstering the faltering economy, and establishing innovative institutions, but Zeng

\footnotetext{
52 Tingyee Kuo and Kwang-Ching Liu, 'Self-Strengthening: the pursuit of Western technology,' in John Fairbank (ed.), The Cambridge History of China, Volume 10, Late Ch'ing, 1800-1911, Part 1, (Cambridge: Cambridge University Press, 1978), p. 491-2.

${ }^{53}$ Yongjin Zhang, China's entry into international society: Beyond the standard of 'civilization', Review of International Studies, 17:1 (1991), pp. 3-16.
} 
Guofan, Li Hongzhang, and Zuo Zongtang are usually considered as the most influential. ${ }^{54}$ What these influential reformers also shared in common was the view of the urgent need to pursue Western technology in the search for 'wealth and strength'. 55

More specifically, Zeng, Li, and their advisors saw the construction of machines not only in narrow military terms, but also as the fundamental basis for industry. ${ }^{56}$ Significantly, key reformists, like Feng Guifen and Li, also saw the construction of Chinese machines as an indicator of China's leading role in international society, as a way to right the wrongs of past humiliations, and as a source of prestige. ${ }^{57}$ Nowhere was this more evident than in the establishment of arsenals and shipyards, the most important of which were the Jiangnan Arsenal and the Fuzhou Navy Yard. ${ }^{58}$ But, among other factors, the prevailing conservatism and prejudice among Confucian literati and court officials hampered China's path towards modernisation and industrialisation. ${ }^{59}$

\footnotetext{
${ }^{54}$ Jonathan D Spence, The Search for Modern China, (2nd edn, New York: W.W. Norton, 1999), p. 192.

${ }^{55}$ Kuo and Liu, 'Self-Strengthening'.

56 Benjamin A. Elman, On Their Own Terms: Science in China, 1550-1900 (Cambridge, MA: Harvard University Press, 2005), p. 360.

${ }^{57}$ Ssu-yu Teng and John K Fairbank, China's Response to the West: A Documentary Survey 1839-1923 (Cambridge, MA: Harvard University Press, 1961), pp. 54, 73.

${ }^{58}$ Elman, On Their Own Terms.

${ }^{59}$ Teng and Fairbank, China's Response, p. 87. The point here, then, is not to espouse the deterministic view that if it were not for these impediments, technological development would occur naturally in China, but to draw attention to the importance of contingent and political factors. The same also applies to my following analysis of technological development in India.
} 
Yet the question remains about how to make sense of the impact of the pursuit of science and technology in late Qing Dynasty in the context of the operation of the 'standard of civilisation'. In his important study on China and Japan's encounter with the expanding European international society, Shogo Suzuki explores how military, technology, and industrial development were key aspects of what the process of learning the competence and skill to be a 'civilised' state involved. ${ }^{60}$ Crucially, however, as Suzuki observes, in contrast to Japanese elites who saw the introduction of Western technology as a key feature of demonstrating their 'civilised' identity, for Chinese elites industry and technology 'served no value as a marker of "civilized" identity, as it did for the members of the Society'. 61

One of Suzuki's major contributions in this regard has been to recognise that Chinese elites did not go beyond the introduction of Western technology and weapons to adopt European-style institutions on a wide scale, which would indicate their intention to conform to the 'standard of civilisation'. Instead, they only linked industrialisation and

${ }^{60}$ Shogo Suzuki, Civilization and Empire.

${ }^{61}$ Ibid, p. 101. 
Western technology to strengthening China militarily as a result of their socialisation into a competitive international environment. ${ }^{62}$

While Suzuki's argument is interesting and important, however, it downplays the fact that a firm analytical separation between becoming militarily powerful and confirming to the social standards as part of what accorded 'civilised' status within international society has two substantial consequences. First, a focus on technology as a sole attribute of military power provides a rather superficial separation between the material and ideational or social dimensions of technology. Still, the author himself shows that Chinese reformers conceived technological modernisation in both military and non-military terms. Second, this tension seems to arise partly because the author accepts, albeit reluctantly, the ti/yong dichotomy, according to which late Qing reformers opted for military modernisation, but not Westernisation. ${ }^{63}$ Yet an uncritical acceptance of the ti/yong schema does not help to account for some of the attitudes towards science and technology that emerged in China as a consequence of its encounter with international society.

Plainly, many Chinese reformists who advocated the introduction of Western weapons and technology operated within what is known as the ti/yong dichotomy, an abbreviated form of the longer prescription to understand 'Chinese studies as the essence, Western

\footnotetext{
${ }^{62}$ Ibid, pp. 89-113.

${ }^{63}$ Ibid, pp. 93-4
} 
studies as function' (zhong xue wei ti, xi xue wei yong). In this regard, they called for the use of Western technology as functional means for Chinese ends, that is, the protection and preservation of Chinese civilisation. Hence, underlying the thought of SelfStrengthening supporters was the belief that "the "substance" (ti) of Confucian culture was essentially invulnerable to the "utility" (yong) of Western technology'. ${ }^{64}$

How then can we make sense of the fact that the views of Chinese reformist elites were seemingly more open-minded and multidimensional than the ti/yong dichotomy suggests? Christopher Hughes suggests that it makes more sense to treat the ti/yong dichotomy as a political act that can be traced back to the efforts by late Qing Dynasty officials 'to mobilize the population by making tradition capable of harnessing the forces of nationalism' during late nineteenth century China. ${ }^{65}$ This helps to illustrate the ways in which the advocates of the Self-Strengthening movement had to engage intellectually with the impact of transnational processes, unleashed by China's encounter with global modernity, which involved drawing on neo-Confucian concepts as part of a process of syncretism. ${ }^{66}$

\footnotetext{
${ }^{64}$ Philip A. Kuhn, Origins of the Modern Chinese State (Stanford, CA: Stanford University Press, 2002), p. 52.

${ }^{65}$ Christopher R. Hughes, 'The enduring function of the Substance/ Essence (Ti/Yong) dichotomy in Chinese nationalism', in William A. Callahan and Elena Barabantseva (eds.), China Orders the World: Normative Soft Power and Foreign Policy, (Baltimore, MD: Johns Hopkins University Press, 2011), p. 119.

${ }^{66} \mathrm{Ibid}, 125$.
} 
In a similar vein, the use of the ti/yong formula by the Chinese reformists can also be seen as a political move to reconcile new conceptions of 'Western science' with traditional forms of knowledge and learning. ${ }^{67}$ In particular, since the mid-nineteenth century, the consolidation of the idea of a universal and teleological 'Western science' led Chinese reformists to resort to a further process of legitimisation and conceptual appropriation. This involved an attempt to encourage and reinterpret traditions and disciplines of knowledge that regarded China as the source of 'Western learning'. ${ }^{68}$ This, in turn, had the effect of rendering the pursuit of 'Western' learning and technology more compatible with Confucian tradition and identity, and, thus, more acceptable to conservatives. The very fact that this position was held among imperial examiners until the early twentieth century is illustrative of how it was used by many conservatives as what Elman calls 'a strategic myth' ${ }^{69}$

Therefore, even if it is conceded that the ti/yong formula has some merit, it is important to recognise the complex nature of this process generally and the multidimensional nature of the views of Chinese reformists on the role of science and technology in particular. True, conservatism and ideology, among other factors, led to the limited and cautious

\footnotetext{
${ }^{67}$ Marwa Elshakry, 'When science became Western: Historiographical reflections', Isis, 101:1 (2010), p. 100.

${ }^{68} \mathrm{Ibid}, \mathrm{p} .102$.

${ }^{69}$ Elman, On Their Own Terms, p. 397-8.
} 
introduction of Western technology during the second half of the nineteenth century. In this respect, perceptions concerning a technology's effects on internal and external security were also important. ${ }^{70}$ But the social pressure created by the need to conform to the operation of technological advancement as an informal 'standard of civilisation' was one of the key drivers behind China's technological modernisation nonetheless.

Equally importantly, the Sino-Japanese War and its aftermath proved to be a turning point for China's engagement with international society generally and science and technology in China in particular. One of the most important consequences of the War was that it gave rise to references to Japan as a great power and as a member of the family of 'civilised nations', whereas perceptions of China as weak and decadent became prevalent. ${ }^{71}$ But what is also noteworthy is that the Sino-Japanese War had the effect of fostering a greater interest in Western learning and science. ${ }^{72}$

More broadly, in the years following the War, a series of events conspired to further destabilise what was already a volatile domestic political environment, which created in

\footnotetext{
${ }^{70}$ Jon Schmid and Jonathan Huang, 'State adoption of transformative technology: Early railroad adoption in China and Japan', International Studies Quarterly, 61: 3 (2017), pp. 570-583. Schmid and Jonathan Huang make this argument in the context of discussing China's slow adoption of railways, but they also highlight the importance of cultural and civilisational factors in Chinese views about foreign technology and ideas in the nineteenth century.

${ }^{71}$ S.C.M. Paine, The Sino-Japanese War of 1894-1895: Perceptions, Power and Primacy (Cambridge: Cambridge University Press, 2003), pp. 18-9.

${ }^{72}$ Elman, On Their Own Terms, pp. 398-9.
} 
turn the preconditions for the birth of the 'modern' Chinese state in 1911, ushering in the Republican era. Crucially, however, the broader question of the relationship between science and technology and China's struggle with global modernity remained at the heart of subsequent events. Nowhere was this more apparent than in the May Fourth Movement. Indeed, an important feature of the movement was the degree to which many intellectuals espoused a complete break with Confucianism and Chinese tradition in favour for an embrace of modernisation or Westernisation in all key facets of Chinese culture, from literature and ethics to philosophy and politics. ${ }^{73}$

Significantly, as Rana Mitter points out, 'a faith in science and technology, linked with ideas of national salvation and reform', appeared to many to be the solution to China's manifold problems. ${ }^{74}$ Equally, the key underlying assumption behind advocating the creation of a new, modern civilisation to 'save China' was the idea that science and democracy constituted the essence of modern Western civilisation, which was evident in the famous slogans of 'Mr Science' and 'Mr Democracy'. ${ }^{75}$ It was in this context that a new generation of scientists and engineers, many of whom were educated abroad, aspired

\footnotetext{
${ }^{73}$ Tse-tung Chow, The May Fourth Movement: Intellectual Revolution in Modern China (Cambridge, MA: Harvard University Press, 1960), p. 359.

${ }^{74}$ Rana Mitter, A Bitter Revolution: China's Struggle with the Modern World (Oxford: Oxford University Press, 2004), p. 101.

${ }^{75}$ Chow, The May Fourth Movement, pp. 359, 59.
} 
to save China through science and technology. ${ }^{76}$ Part of this gradual metamorphosis was also the growing importance of industrial development over other sectors of the economy in order to turn China into a modern, industrial, and technologically advanced country under the government of Chiang Kai-shek. ${ }^{77}$

Consequently, the most general point to make is that the fundamental interaction between the state, power, and technological hierarchies in international society, which was at the heart of late Qing reformists and Republican China, would continue to shape conceptions about the role of science and technology in Communist China, as I shall discuss later.

\section{India, Modernity, and the Making of the Postcolonial Technological State}

The importance of the close links between science, technology, and colonial rule in British India has attracted much attention in the scholarly literature that deals with the

\footnotetext{
${ }^{76}$ Zuoyue Wang, 'Saving China through science: The science Society of China, scientific nationalism, and civil society in Republican China', Osiris, 17 (2002), pp. 291-322.

${ }^{77}$ William C. Kirby, 'Technocratic organization and technological development in China: The nationalist experience and legacy, 1928-1953', in Denis Fred Simon and Merle Goldman (eds.), Science and Technology in Post-Mao China (Cambridge, MA: Harvard University Press, 1989), p. 29.
} 
social history of science and technology in India. ${ }^{78}$ As many have noted, the British saw science and technology as important features of their 'civilising mission' as well as a manifestation of their superior civilisation. ${ }^{79}$ A detailed account of science, technology, colonialism and modernity in the context of the British Empire and its impact on India is beyond the scope of this article, but some of the key aspects of this process are worth highlighting here. First, the period of British rule in India witnessed the effort by the colonisers to 'enlighten' the natives through science as a source of reason, which had the effect of positioning the function of science both as culture and power. In this regard, the very idea of Western modernity was embedded in the scientific outlook of the colonial and imperial project in the sense that the authority and legitimacy of universal reason signified science and technology as tools of the British rule in India. ${ }^{80}$

Second, an important feature of the projection of India as a modern colony was the development of infrastructures, practices, and institutions associated with the representation of science and technology as configurations of Western authority and universal reason. This was manifested in the ways in which the colonial state used modern

\footnotetext{
78 See, for example, David Arnold, The New Cambridge History of India: Science, Technology and Medicine in Colonial India. III-5 (Cambridge: Cambridge University Press, 2000); Deepak Kumar, Science and the Raj: A Study of British India (2nd edn, Oxford: Oxford University Press, 2006); Gyan Prakash, Another Reason: Science and the Imagination of Modern India (Princeton, NJ: Princeton University Press, 1999).

${ }^{79}$ Prakash, Another Reason, p. 3; Arnold, The New Cambridge History of India, pp. 15, 22.

${ }^{80}$ Prakash, Another Reason, p. 4.
} 
techniques of governmentality from irrigation and mining to the railways and the telegraph system. ${ }^{81}$ Indeed, for Marquis of Dalhousie, who was Governor-General of India from 1848 to 1856 , the telegraph and the postal system represented the two of the three 'great engines of social improvement' of colonial India. In his view, the third engine was the establishment of a network of railways, which increasingly epitomised the moral and material superiority of the coloniser over the colonised. ${ }^{82}$ However, it should be noted that this process was further consolidated after the 1857 Mutiny that placed India under direct Crown rule. Against the backdrop of further centralisation and tightening colonial control, the development of science and technology became one of the largest statesponsored undertakings under the Public Works Department. ${ }^{83}$

Third, the hierarchy of civilisations according to material accomplishments was also reflected in the reproduction of social hierarchies between the coloniser and the colonised. Not only was the Indian civilisation defined as stagnant and backward, but the Indian worker had to be subordinated to the British engineer 'as civiliser' ${ }^{84}$ Equally, as Daniel Headrick observes, the British were willing to upskill the Indians only to a certain point,

\footnotetext{
${ }^{81}$ Ibid, pp. 11, 159-70.

82 Daniel R. Headrick, The Tentacles of Progress: Technology Transfer in the Age of Imperialism, 18501940 (New York, NY: Oxford University Press, 1988), p. 64; Adas, Machines, pp. 223, 225.

${ }^{83}$ Zaheer Baber, The Science of Empire: Scientific Knowledge, Civilization, and Colonial Rule in India, (Albany, NY: State University of New York Press, 1996), pp. 184-212; Prakash, Another Reason, p. 4.

${ }^{84}$ Adas, Machines, pp. 235-6.
} 
beyond which 'they withheld the culture of technology' ${ }^{85}$ Yet although the consolidation of colonial rule in India led to the development of colonial structures that facilitated the institutionalisation of Western scientific research and technological projects, which had a decisive impact on the indigenous system of science, Indian scientists were key agents in promoting the introduction of Western science and technology. In other words, it is important to acknowledge that the introduction of Western science and technology in India cannot be understood as a simple process of imposing Western traditions of knowledge on indigenous ones. ${ }^{86}$

As a result, during the second half of the nineteenth century an Indian scientific elite emerged that could identify with the project of Western modernity. A key aspect of this effort was the creation of institutions like the Indian Association for the Cultivation of Science, which was formally established in 1876 with the aim of educating Indian scientists on basic research under native control and management. Notably, one of its students, C V Raman, would become the first Indian to be awarded the Nobel Prize for theoretical physics in $1930 .{ }^{87}$

\footnotetext{
${ }^{85}$ Headrick, The Tentacles of Progress, p. 345.

${ }^{86}$ Arnold, The New Cambridge History, pp. 12-14; Baber, The Science of Empire, p. 251-2.

${ }^{87}$ Baber, The Science of Empire, pp. 229-30.
} 
But what merits emphasis is that the embracement of modernity by the Indian scientific community became gradually interwoven with the rise of nationalism, which marked the growing intersection of science and politics. As Gyan Prakash argues, it became increasingly accepted among anti-colonial nationalists that 'to be a nation was to be endowed with science'. ${ }^{88}$ This involved the 'rediscovery' of a body of indigenous scientific traditions that was appropriated as congruous with Western science. Concomitant with this was a process of conceptual appropriation based on the idea that these traditions of science, technology, and knowledge were the past of the Indian nation, imbued with universal thought and rationality. It was in this context that Hindu science soon emerged as 'symbol for the modern nation' and as a way to indigenise modernity. In turn, the claim by nationalists that Hindu science was an expression of universality and rationality reconfigured the colonial state defined by modern techniques, practices, and infrastructures as a national site that had to become independent. ${ }^{89}$

As a consequence, not only was science at the heart of the imagination and institution of India as a colonial project, but also became essential in the reconstruction of India as an independent nation. This was evident in the widely held assumption among nationalists that India succumbed to colonial rule because it did not manage to become modern. In

\footnotetext{
${ }^{88}$ Prakash, Another Reason, p. 7.

${ }^{89}$ Ibid, pp. 7-11.
} 
their view, as Priya Chacko notes, it was India's failure to develop a scientific outlook, and thus, to meet the 'standard of civilisation' set by the European international society that brought India under British control. ${ }^{90}$ Indeed, in the postcolonial world the development of a scientific outlook emerged as an indicator of national character predicated on the idea that the nexus between modern science and the nation-state was a key factor in the making of the dominant European powers. In response, postcolonial states felt compelled to adapt and imitate these practices. ${ }^{91}$

The colonial experience, therefore, led to the conviction that India was backward, which in turn gave rise to the desire of mimicking 'Western' practices, including science and technology. But whereas the increasing acceptance of modernity among Indian elites was seen as an inescapable process of the emerging international order, given the country's colonial past, India's response to modernity could not be underpinned by simple mimicry. India had to foster a different modernity 'on its own terms'. ${ }^{92}$ Put differently, the mimicry of Western modernity had to be counterbalanced with ambivalence towards Western modernity in order to highlight India's difference as a postcolonial civilisational entity. ${ }^{93}$

\footnotetext{
${ }^{90}$ Priya Chacko, 'The search for a scientific temper: Nuclear technology and the ambivalence of India's postcolonial modernity', Review of International Studies, 37:1 (2011): p. 186.

${ }_{91}$ Carol E. Harrison and Ann Johnson, 'Introduction: Science and national identity', Osiris, 24:1 (2009): pp. 1-14.

92 Prakash, Another Reason, p. 200-1.

${ }^{93}$ Chacko, 'The search for a scientific temper'.
} 
That said, the key point to emphasise is that technological advancement as a civilisational standard in the long nineteenth century was implicated in the emergence of a powerful postcolonial ideology of science and technology under the leadership of Nehru that signified the pursuit of key technological projects as normative indicators of the postcolonial state's power, status, and modernity, as I explain below.

\section{Civilisation, Modernity, and Technological Hierarchies}

In recent years, there has been a growing body of literature that seeks to illustrate the ways in which the logic of the 'standard of civilisation' resonates today, reflected mainly in certain liberal norms, principles, and practices, what David Fidler calls the 'standard of liberal, globalized civilization' ${ }^{94}$ These include, but are not limited to, the following: human rights ${ }^{95}$; economic and financial standards ${ }^{96}$; the status of women ${ }^{97}$; democratic

\footnotetext{
${ }^{94}$ David P. Fidler, 'A kinder, gentler system or capitulations? International law, structural adjustment policies, and the standard of liberal, globalized civilization', Texas International Law Journal, 35:3 (2000), pp. 387-413.

${ }_{95}$ Jack Donnelly, 'Human rights: A new Standard of Civilization?', International Affairs, 74:1 (1998), pp. $1-23$.

${ }^{96}$ Gerrit W. Gong, 'Standards of civilization today', in Mehdi Mozaffari (ed.), Globalization and Civilizations (London: Routledge, 2002), pp. 85-92.

${ }^{97}$ Towns, 'The status of women'.
} 
government $^{98}$; the European Union's membership conditionality and other policies ${ }^{99}$ and non-proliferation, arms control, and the conduct of warfare. ${ }^{100}$ This has been evident, of course, in the generation of new categories of outsiders to the liberal structure of international society, such as 'rogue', 'failed', 'pariah', and 'outlaw' states. ${ }^{101}$

In this context, non-European countries continue to face the same dilemmas of how to respond to the challenges of modernisation, development, and globalisation. As Gerrit Gong notes, 'one cannot speak of "modernization", or the "process of becoming modern", in a historical perspective without referring to what an earlier age called "civilization" and the process of becoming "civilized". ${ }^{102}$ This is an important consideration, for the purposes of this article, especially given how Chinese and Indian elites continue to struggle with the stigmas of "[n]ot being of the "West", being behind the "West", not

\footnotetext{
${ }^{98}$ Christopher Hobson, 'Democracy as Civilisation', Global Society, 22:1 (2008), pp. 75-95.

99 Kalyspo Nicolaidis, Claire Vergerio, Nora Fisher Onar, and Juri Viehoff, 'From metropolis to microcosmos: The EU's new standards of civilisation', Millennium, 42:3 (2014), pp. 718-745; Yannis A. Stivachtis, 'Civilization and international society: The case of European Union expansion', Contemporary Politics, 14:1 (2008), pp. 71-89.

${ }^{100}$ Helen M. Kinsella, The Image before the Weapon: A Critical History of the Distinction Combatant and Civilian (Ithaca, NY: Cornell University Press, 2011); Krause and Latham, 'Constructing nonproliferation', pp. 41-4; Ritu Mathur, 'The West and the rest: A civilizational mantra in arms control and disarmament?', Contemporary Security Policy, $35: 3$ (2014), pp. 332-55; Price, 'A Genealogy'; and Tannenwald, 'The nuclear taboo', p. 437.

${ }^{101}$ Simpson, Great Powers, pp. 278-316; Bowden, The Empire of Civilization, pp. 17, 186, 190.

${ }^{102}$ Gong, 'Standards of civilization today', p. 80.
} 
being "modern" enough, not being developed or industrialized or secular or civilized or Christian or democratic enough'. ${ }^{103}$

Not surprisingly, therefore, China has attracted much attention in the scholarly literature that deals with its engagement with present civilisational standards that underpin the current normative structure of international society. ${ }^{104}$ Unlike China, however, India's encounter story has been largely neglected presumably because it appears as a somewhat straightforward case. India initially succumbs to colonial rule so its struggle with modernity is understood as part of the broader issue pertaining to the relationship of ruler and ruled. ${ }^{105}$

Be that as it may, by the early twentieth century the tendency among states to cast technological achievements as markers of modernity was already consolidated. Indeed, as Harrison and Johnson observe, 'the first states to take advantage of the power this nexus [between science and the nation-state] produced became globally dominant and were widely imitated'. ${ }^{106}$ For example, despite the significant differences between British and German understandings of the national importance of technology, the Anglo-German

\footnotetext{
103 Ayşe Zarakol, After Defeat: How the East Learned to Live with the West (Cambridge: Cambridge University Press, 2011), p. 4.

${ }^{104}$ Xiaoming Zhang, 'China in the conception of international society: the English School's engagements with China', Review of International Studies, 37:2 (2011), pp. 763-86.

105 Buzan, 'The 'Standard of Civilisation', p. 581.

${ }^{106}$ Harrison and Johnson, 'Introduction', p. 3.
} 
political and economic competition of that period helped to cultivate a culture of modernity that was conductive to technological innovation, engrained in a sense of national purpose. This led observers in Britain and Germany to see passenger ships, civilian vessels, and airships as indicators of their countries' international status and national prestige that exhibited a country's creative potential, international leadership, and national aspirations. ${ }^{107}$

To be sure, the first and the second World Wars have had a profound impact on the discourse of civilisation and notions of European superiority over non-European societies. ${ }^{108}$ Yet the same cannot be said about the role of technology as an informal standard of modernity and hierarchy in international society. At a time when the erstwhile European powers were trying to recover from the devastating consequences of the two wars, technological development was increasingly becoming a key aspect of the growing influence of the United States and the Soviet Union as an indicator of national purpose, international status, and global aspirations amid the Cold War. However, it should be

\footnotetext{
${ }^{107}$ Bernhard Rieger, Technology and Culture of Modernity in Britain and Germany 1890-1945 (Cambridge: Cambridge University Press, 2005), pp. 224-30.

${ }^{108}$ Bowden, The Empire of Civilization, p. 126.
} 
noted that one of the most important consequence of the Cold War was that it redefined the nexus between techno-scientific practices and the nation-state globally. ${ }^{109}$

Concomitant with this process was the reworking of the relationship between technology and the state in the context of modernisation. As was mentioned previously, in many ways, modernisation, as a term associated with different levels of human worth, came to supplant previous ideas about civilisation and technological accomplishments. ${ }^{110}$ Consequently, as Brett Bowden (2009: 186) notes, the 'efficacy of science and technology' can be understood as one of a number of criteria that states need to meet in order to be recognised as full members of international society in the twenty-first century. ${ }^{111}$ What is more, as Barry Buzan and George Lawson point out, contemporary attempts at restricting the spread of advanced weapons, including nuclear weapons and missile technology, to the periphery of international society is reflective of the nineteenth century colonial pattern of demarcating the 'civilised' at home and the 'barbaric' abroad. ${ }^{112}$

109 Gabrielle Hecht (ed.), Entangled Geographies: Empire and Technopolitics in the Global Cold War (Cambridge: MIT Press, 2011); Naomi Oreskes and John Krige (eds), Science and Technology in the Global Cold War (Cambridge MA: MIT Press, 2014).

${ }^{110}$ Adas, Machines, p. 402-3; Bowden, The Empire of Civilization, pp. 69-72.

${ }^{111}$ Bowden, The Empire of Civilization, p. 186.

112 Buzan and Lawson, The Global Transformation, p. 185. 
Therefore, highly visible technological projects, such as nuclear and space programmes, have continued to provide a substitute for a mechanism of exclusion in international society as normative symbols of modernity, progress, and technological prowess, especially from 1945 onwards. This has had the effect of reproducing the distinction between insiders and outsiders based on the possession of specific technologies as an institutionalised, but informal form of hierarchy in international society. A number of points are worth noting here. First, scholars have highlighted the ways in which the advent of the Nuclear Age signified a global condition that defined nuclear power as a new form of reproducing insiders and outsiders interwoven with what Hugh Gusterson has called 'nuclear orientalism'. ${ }^{113}$ This has been epitomised by the distinction between the nuclear 'Haves' and the 'Have Nots' ${ }^{114}$ In addition, useful accounts of cases concerning the intersection of technology, modernity, national identity, culture, and state-building have also been provided. ${ }^{115}$

\footnotetext{
${ }^{113}$ Hugh Gusterson, 'Nuclear weapons and the Other in the Western imagination', Cultural Anthropology, 14:1 (1999), pp. 111-43.

114 Shampa Biswas, Nuclear Desire: Power and the Postcolonial Nuclear Order (Minneapolis, MN: University of Minnesota Press, 2014).

115 See, for example, Peter Fritzsche, A Nation of Fliers: German Aviation and the Popular Imagination (Cambridge, MA: Harvard University Press, 1992); Gabrielle Hecht, The Radiance of France: Nuclear Power and National Identity after World War II (Cambridge: MIT Press, 2009); Timothy Mitchell, Rule by Experts: Egypt, Techno-politics, Modernity (Berkeley, CA: University of California Press, 2002).
} 
Second, as far as China is concerned, scholarly analysis has focused on how a powerful and composite techno-nationalist ideology has informed, and continues to inform, the pursuit of key technological projects, including nuclear, missile, and space projects, ${ }^{116}$ as part of China's enduring quest for wealth and power. ${ }^{117}$ Crucially, the origins of Chinese techno-nationalism can be traced to China's formative experience with the European international society in the nineteenth century. ${ }^{118}$ This serves to highlight the relationship between technological prowess and civilisational hierarchies. As Benjamin Elman (2007: 523), a leading historian of science and technology in China, observes:

If there has been one constant in China since the middle of the nineteenth century, it is that imperial reformers, early Republicans, and Chinese Communists have all prioritized modern science and technology. We can no longer afford to undervalue the place of science in modern contemporary China. China's plans to send space

\footnotetext{
${ }^{116}$ Evan A. Feigenbaum, China's Techno-Warriors: National Security and Strategic Competition from the Nuclear to the Information Age (Stanford, CA: Stanford University Press, 2003); and Tai Ming Cheung, Fortifying China: The Struggle to Build a Modern Defense Economy (Ithaca, NY: Cornell University Press, 2009), pp. 237-41. For an insightful analysis of the importance of Chinese techno-nationalism as a composite ideology, see Christopher R. Hughes, Chinese Nationalism in the Global Era (Abingdon: Routledge, 2006). On the original use of the concept of techno-nationalism, see Richard J. Samuels, Rich Nation, Strong Army: National Security and the Technological Transformation of Japan (Ithaca, NY : Cornel University Press, 1994).

117 On China's continuing quest for wealth and power, see Orville Schell and John Delury, Wealth and Power: China's Long March to the Twenty-First Century (London: Little, Brown, 2013).

${ }^{118}$ Feigenbaum, China's Techno-Warriors, pp. 225-7; Tai Ming Cheung, Fortifying China, p. 237.
} 
expeditions to the moon and Mars in the twenty-first century are in part a response to the shock of heavy-handed Western and Japanese imperialism since $1850 .{ }^{119}$

Third, with regards to India, there has been a growing interest in key science and technology projects as an important aspect of the intersection of India's national identity and state-building since independence. ${ }^{120}$ Part of this debate has also been a focus on how high-prestige projects, such as India's nuclear programme, have become an embedded practice of its postcolonial identity and 'civilisational exceptionalism', signifying national techno-social and techno-political projects as markers of power, status, and modernity. ${ }^{121}$ Likewise, recent works have showed the ways in which India's space effort has been couched in the language of modernisation and progress in a postcolonial context. $^{122}$

In light of the above, the key point that emerges from this brief discussion is that it is necessary to take into consideration the ways in which technological advancement was

\footnotetext{
119 Benjamin A. Elman, 'New directions in the history of modern science in China: Global science and comparative history', Isis, 98:3 (2007), p. 523.

${ }^{120}$ See, among others, Robert S Anderson, Nucleus and Nation: Scientists, International Networks and Power in India (Chicago, IL: University of Chicago Press, 2010); and Jahnavi Phalkey, Atomic State: Big Science in Twentieth-century India (Ranikhet: Permanent Black, 2013).

${ }^{121}$ Itty Abraham, The Making of the Indian Atomic Bomb: Science, Secrecy and the Postcolonial State (London: Zed Books, 1998); Chacko, 'The Search for a scientific temper'.

${ }_{122}$ Asif Siddiqi, 'Making space for the nation: Satellite television, Indian scientific elites, and the Cold War', Comparative Studies of South Asia, Africa and the Middle East, 35:1 (2015), pp. 35-49.
} 
seen as an informal 'standard of civilisation' in the nineteenth century, if we want to understand the continuing influence of conceptions of technology associated with prestige, status, and national identity in the current international order. A focus on China and India helps to illustrate this. Not only did the emergence of technological advancement as a civilisational standard have an impact on the pursuit of technology in China and India during the long nineteenth century, but the logic of this standard remains entrenched in certain Chinese and Indian techno-scientific projects that remake technological hierarchies within today's international society.

\section{Concluding Remarks}

Engaging with Science and Technology Studies (STS), recent IR scholarship has brought attention to the study of the politics of technology by highlighting the ways in which technology is socially constructed in global politics. This is a welcome contribution to our understanding of the increasingly complex interplay between technology and the international, not least because it helps us to move beyond technological determinism and ahistoricism that have characterised much of the contemporary IR literature that deals with technology. However, in this article I have argued that this emerging body of 
scholarship misses certain aspects of how technology is shaped by international society. What we need, therefore, is to adopt a new thinking about the global politics of technology that relates technology with international society.

In pursuing this line of enquiry, I have outlined one way through which international society has influenced technology by considering the emergence of technological advancement as a 'standard of civilisation' in the nineteenth century. As I have shown, an important feature of the expansion of the European society of states into the nonEuropean world was the social construction of technological advancement as a civilisational standard that differentiated the 'society of civilised states' from nonEuropean societies, with a particular focus on China and India. This process was becoming enmeshed in a techno-scientific orientalist discourse that engendered hierarchical conceptions of modern science and technology, which went hand in hand with the construction of civilisational hierarchies and other standards of 'civilisation', by each feeding into the other. To further illustrate that point, the article has considered the ways in which the emergence of technological advancement as a 'standard of civilisation' had an important and enduring impact on Chinese and Indian conceptions of science and technology as part of their engagement with international society.

The emergence of technological advancement as a 'standard of civilisation' in the nineteenth century has important implications for today's international society. Although 
the first and the second World Wars have had a profound effect on the discourse of civilisation and notions of European superiority over non-European societies, sites of inclusion and exclusion on the basis of technological capabilities continued, and still continue, to define distinctions between outsiders and insiders and, thus, forms of hierarchy, power, and status in international society. Therefore, considering technology as a civilisational standard helps to illustrate how China and India's formative experience with the European international society still informs a powerful variant of technonationalism, associated with high-profile engineering projects, such as nuclear and space programmes. This becomes an important consideration, especially given how China and India remain enmeshed in a process of negotiating their role as non-Western emerging technological powers in the context of modernisation, development, and globalisation.

In closing, it is important to emphasise that bringing technology into international society should be seen as a complementary move that can be extended further to incorporate principal insights from the burgeoning STS-IR literature. In this context, rather than focusing on how technology affects global politics or how international society influences technology, it is worth considering how the English School and STS can complement the other as part of an effort to examine the co-constitution and coimplication of technology and international society. This can also involve an analysis that relates technology with other aspects of the research agenda of the English School, such 
as the study of primary institutions (the balance of power, great power management, diplomacy, sovereignty, law, war, the market, and so on). ${ }^{123}$ A key question then is how the primary institutions of international society enable and constrain the development of technology and how technology introduces changes into the primary institutions. It should also be noted that the cases of China and India are by no means exhaustive. Therefore, it is worth considering other cases of state and non-state actors and processes and what these can tell us about technology and international society. In light of the above, the argument put forward in this article helps to open new avenues for exploring the growing dynamics of technology and global politics, on which future theoretical and empirical work will hopefully build.

\section{Acknowledgements}

I would like thank Barry Buzan, William Callahan, Daniel Deudney, Aaron McKeil, Kyriakos Mikelis, Barbara Yoxon, and the journal's anonymous reviewers for their helpful comments on earlier drafts of this article. I am also particularly grateful to Christopher R Hughes for the interesting conversations and his constructive feedback on earlier versions of this article. The usual disclaimer applies.

\footnotetext{
${ }^{123}$ For a recent overview of the research agenda of the English School, see: Barry Buzan and Laust Schouenborg, Global International Society: A New Framework for Analysis (Cambridge: Cambridge University Press, 2018).
} 
